\title{
Increasing collaboration between China and India in the environmental sciences to foster global sustainability
}

\author{
Eben Goodale, Christos Mammides, Wambura Mtemi, \\ You-Fang Chen, Ranjit Barthakur, Uromi Manage Goodale, Aiwu Jiang, \\ Jianguo Liu, Saurav Malhotra, Madhava Meegaskumbura, Maharaj K. Pandit, \\ Guangle Qiu, Jianchu Xu, Kun-Fang Cao 무, Kamaljit S. Bawa
}

Received: 30 January 2021 / Revised: 17 September 2021/Accepted: 24 November 2021/Published online: 28 December 2021

\begin{abstract}
As the two largest countries by population, China and India have pervasive effects on the ecosphere. Because of their human population size and long international boundary, they share biodiversity and the threats to it, as well as crops, pests and diseases. We ranked the two countries on a variety of environmental challenges and solutions, illustrating quantitatively their environmental footprint and the parallels between them regarding the threats to their human populations and biodiversity. Yet we show that China and India continue to have few coauthorships in environmental publications, even as their major funding for scientific research has expanded. An agenda for collaboration between China and India can start with the shared Himalaya, linking the countries' scientists and institutions. A broader agenda can then be framed around environmental challenges that have regional patterns. Coordinated and collaborative research has the potential to improve the two countries' environmental performance, with implications for global sustainability.
\end{abstract}

Keywords Conservation - Developing countries · Environmental science $\cdot$ Pollutants $\cdot$ Sustainability

\section{INTRODUCTION}

The conflict in 2020 at the border between China and India (Goldman 2020) should serve as a reminder about the opportunities and obstacles to foster global sustainability and biodiversity conservation through coordinated action. The two mega-biodiverse countries of the world (Mittermeier and Mittermeier 1997) include parts of five global biodiversity hotspots (Mittermeier et al. 2004), one of which, the Himalaya mountain range with its associated large river basins, is of continental scale (Pandit 2017; Xu et al. 2019). Equally important is how their large human populations $(36.3 \%$ of the world in 2019 ; population.un.org), economies (19.0\% of the cumulative global gross domestic product [GDP] in 2018; data.worldbank.org), and their trajectories of economic growth (annual rates, respectively of $9.3 \%$ and $6.4 \%$ over the 30 years previous to 2019; World Bank data) impact the regional and global environment (Dahlman 2012). Here, we compare the two countries' environmental footprints, providing their global rankings on environmental issues that threaten to overshoot planetary boundaries. Given their combined size and economic impact, shared environmental threats and footprints, and the richness of their biodiversity and associated ecosystem services, we will argue that the two countries hold the key to global sustainability.

Unfortunately, because of cultural and linguistic differences, and the history of geopolitical tensions like the border dispute, cooperation in the environmental sciences between the two countries has been limited (Bawa et al. 2010). Yet transboundary coordination in environmental problem-solving and conservation between neighboring or regional countries is increasingly seen as both more efficient and effective than purely within-country planning (Kark et al. 2009; Mason et al. 2020; Mammides et al. 2021). Also, it is essential to incorporate interactions between neighboring and distant countries to achieve the UN Sustainable Development Goals (SDGs, Liu 2018). We set out to measure the pulse of collaboration between the two countries, given that over the past decade, they have both sought to enlarge their presence in the innovation economy with an increased emphasis on research and development (Gackstatter et al. 2014), particularly in higher education (Jöns and Hoyler 2013). To do this, we analyzed co-authorship trends in research articles in the environmental sciences, and looked at the growth in 
research funding. Equipped with evidence of a lack of collaboration, despite increasing research funding, we then developed an agenda for collaboration and coordination among the two countries in the environmental sciences. Such an agenda aims to provide the knowledge base and policy recommendations to transform their shared threats into opportunities, reduce their environmental footprint, and help the world move towards sustainability.

\section{COMPARING CHINA AND INDIA IN THEIR ENVIRONMENTAL FOOTPRINTS}

While there are summary articles on the overall environmental health of China (Liu and Diamond 2005; Liu et al. 2018), articles on India tend to be more issue-specific (e.g., Ghosh-Harihar et al. 2019; India State-Level Disease Burden Initiative Air Pollution Collaborators 2019). Further, environmental report cards, e.g., the Environmental Performance Index (EPI; epi.yale.edu), evaluate the environmental conditions that citizens of countries experience, but not necessarily the impact of the countries beyond their borders. Hence, there is a need for a fresh analysis comparing the environmental footprints of these two countries.

We used the planetary boundaries concept (Steffen et al. 2015) as an overarching framework to identify environmental problems. Of the nine issues described therein, we cover all but stratospheric ozone depletion, an issue that has stabilized thanks to concerted international efforts (Solomon et al. 2016). For biodiversity and ecosystem services, we rely on the EPI global rankings on these topics, as they use multiple data sources to address their complex nature. We acknowledge that the issues included in this study are selective, based on the ability to get ranked data at a country-level. For example, the illegal wildlife trade, a global issue important to biosphere integrity, was excluded because of the difficulty of collecting ranked information on the many species listed in CITES (https:// cites.org).

We find the two countries standout globally when ranking environmental problems at the country-level: for thirteen issues for which the countries were ranked as to their contributions (not including the EPI ratings), China was ranked first eight times and India was ranked first three times (Table 1). As most of these data represent totals at the country level, these patterns are a consequence of the large population sizes and geographic extents of these countries. In contrast, air pollution data is expressed as an average exposure, adjusted to the number of people exposed (https:// www.stateofglobalair.org), and hence demonstrates that at the per capita level, the citizens of the two countries have especially elevated threats to their health. A limitation is that the analysis is frozen in time, with the information gathered between 2010 and 2020, depending on the issue examined. However, because of India's higher population growth rate and consequent growth in emissions, it is likely to overtake China in some of these rankings over time. For example, this may have already occurred with $\mathrm{SO}_{2}$ emissions ( $\mathrm{Li}$ et al. 2017), and it is expected to occur in mercury emissions over the next decade (AMAP/UN Environment 2019).

The issues in Table 1 vary in the scale at which the impacts are felt. Our categories of scale are qualitative, and the scale of the effects related to any specific planetary boundary may be greater than those indicated for the specific issue listed in the table: for example, aerosols of black carbon are known to affect the South Asian monsoon, producing regional level effects (Ramanathan et al. 2005). Climate change is clearly global, but other issues stretch from the regional to the global, including emissions to the atmosphere, such as $\mathrm{N}$ and $\mathrm{Hg}$ emissions, that lead to widespread deposition. The global supply chain, represented in our analysis by palm oil and roundwood imports, applies pressure on Asian countries, as well as those further afield. Effects of biodiversity conservation, or of persistent organic pollutants, will mostly be felt in the home country, but will affect other countries through transboundary movement of animal species, especially migrants, and water. At the local level, China and India share important environmental health issues that affect their populations. For example, the deaths of 1.2 million people in each country in 2017 were attributable to air pollution (https:// www.stateofglobalair.org/). Moreover, 1 billion people in India and 900 million in China are thought to be affected by moderate or severe water scarcity for at least one month per year (Mekonnen and Hoekstra 2016). Indeed, at the local level the data support the conclusions of EPI, which ranks both countries as below average in environmental performance for their respective GDPs (in their 2020 report, China is ranked for environmental performance as 120th, and India 168th, of 180 countries).

\section{ENVIRONMENTAL SOLUTIONS AND NOVEL POLICIES}

Overemphasis on the negatives, however, neglects the important role these countries can play when they tackle problems assertively. Due to their policies as well as their size, the two countries are also among the global leaders in carbon sequestration (by expanding natural forests, afforestation and agriculture in China, though largely due to agriculture in India; Chen et al. 2019) and renewable energy (see "Solutions" in Table 1). Both countries have played constructive roles in building international environmental treaties, and specifically in addressing climate change (Karakır 2018). 
Table 1 China and India's contributions to, or experience of, environmental issues, both problems and solutions. The selection of issues is guided by the planetary boundaries concept (Steffen et al. 2015), as shown in the second column; we also indicate roughly the scale of the impacts of the issue and whether it is constrained to the country itself ('local'), or is regional or global. The number represents the global rank of the country in its contribution to a problem/solution. Note that most rows indicate a total for the whole country. In contrast, air pollution metrics (ozone, $\mathrm{PM}_{2.5}$ ), estimated by the Health Effects Institute, represent population-weighted annual average concentrations (https://www. stateofglobalair.org/). The Environmental Performance Index (EPI; https://epi.yale.edu/)'s 2020 report ranks 180 countries, using seven metrics for their biodiversity index and three metrics for their ecosystem services index, and using cumulatively seven data sources. For the EPI indices, smaller numbers indicate better performance

\begin{tabular}{|c|c|c|c|c|c|c|c|}
\hline Environmental issue & Planetary boundary & Impact level & Unit & China & India & $\begin{array}{l}\text { Year of } \\
\text { assessment }\end{array}$ & References \\
\hline \multicolumn{8}{|l|}{ Problems } \\
\hline $\mathrm{CO}_{2}$ emissions & $\begin{array}{l}\text { Climate change; } \\
\text { ocean } \\
\text { acidification }\end{array}$ & Global & $\mathrm{MtCO}_{2} \mathrm{e}$ & 1 & 3 & 2018 & $\begin{array}{l}\text { https://www.climatewatch } \\
\text { data.org/ghg-emissions }\end{array}$ \\
\hline $\begin{array}{l}\text { Other greenhouse gases } \\
\left(\mathrm{CH}_{4}, \mathrm{~N}_{2} \mathrm{O}, \mathrm{F} \text {-gas }\right)\end{array}$ & Climate change & Global & $\mathrm{MtCO}_{2} \mathrm{e}$ & 1 & 3 & 2018 & $\begin{array}{l}\text { https://www.climatewatch } \\
\text { data.org/ghg-emissions }\end{array}$ \\
\hline Nitrogen deposition & Biochemical flow & Regional & $\mathrm{kg}$ & 1 & 2 & 2016 & Ackerman et al. (2019) \\
\hline Mercury emission & Biochemical flow & Regional & Tonnes & 1 & 4 & 2015 & $\begin{array}{l}\text { AMAP/UN Environment } \\
\text { (2019) }\end{array}$ \\
\hline Plastic waste production & Novel entities & $\begin{array}{l}\text { Regional (ocean } \\
\text { circulation)/local }\end{array}$ & $\begin{array}{l}\text { Million } \\
\text { metric tons }\end{array}$ & 1 & 2 & 2015 & $\begin{array}{l}\text { Lebreton and Andrady } \\
\text { (2019) }\end{array}$ \\
\hline $\begin{array}{l}\text { Waste from electrical and } \\
\text { electronic equipment }\end{array}$ & Novel entities & Local & $\begin{array}{l}\text { Million } \\
\text { metric } \\
\text { tonnes }\end{array}$ & 1 & 4 & 2016 & Baldé et al. (2017) \\
\hline DDT & Novel entities & $\begin{array}{l}\text { Regional (trans- } \\
\text { boundary wildlife)/ } \\
\text { local }\end{array}$ & $\begin{array}{l}\text { Tonnes } \\
\text { produced }\end{array}$ & 3 & 4 & $\begin{array}{l}\text { Through } \\
2019\end{array}$ & Fiedler et al. (2019) \\
\hline Atmospheric sulfur $\left(\mathrm{SO}_{2}\right)$ & Aerosol loading & Local & $\mathrm{Tg}$ & 1 & 2 & 2015 & Aas et al. (2019) \\
\hline $\begin{array}{l}\text { Ambient ozone }\left(\mathrm{O}_{3}\right) \\
\text { pollution }\end{array}$ & Aerosol loading & Local & $\mathrm{ppb}$ & 44 & 3 & 2019 & $\begin{array}{l}\text { https://www. } \\
\text { stateofglobalair.org }\end{array}$ \\
\hline $\begin{array}{l}\text { Ambient fine particulate } \\
\text { matter }\left(\mathrm{PM}_{2.5}\right)\end{array}$ & Aerosol loading & Local & $\mu \mathrm{g} / \mathrm{m}^{3}$ & 29 & 1 & 2019 & $\begin{array}{l}\text { https://www. } \\
\text { stateofglobalair.org }\end{array}$ \\
\hline $\begin{array}{l}\text { Annual freshwater } \\
\text { withdrawals }\end{array}$ & Freshwater & Regional/local & Cubic meters & 2 & 1 & 2010-2014 & $\begin{array}{l}\text { https://data.worldbank.org/ } \\
\text { indicator }\end{array}$ \\
\hline Import of palm oil & Land-use change & Global/regional & $\begin{array}{l}\text { Million } \\
\text { tonnes }\end{array}$ & 2 & 1 & 2018 & DAC\&FW (2019) \\
\hline Import of roundwood & Land-use change & Global/regional & Million $\mathrm{m}^{3}$ & 1 & 7 & 2018 & FAO (2018) \\
\hline Ecosystem services & Land-use change & Local & $\begin{array}{l}\text { Country } \\
\text { ranking by } \\
\text { EPI }\end{array}$ & 90 & 93 & $\begin{array}{l}2020 \\
\text { ranking }\end{array}$ & https://epi.yale.edu \\
\hline Biodiversity conservation & Biosphere integrity & $\begin{array}{l}\text { Local/regional (trans- } \\
\text { boundary species) }\end{array}$ & $\begin{array}{l}\text { Country } \\
\text { ranking by } \\
\text { EPI }\end{array}$ & 172 & 148 & $\begin{array}{l}2020 \\
\text { ranking }\end{array}$ & https://epi.yale.edu \\
\hline \multicolumn{8}{|l|}{ Solutions } \\
\hline Afforestation (in) & Land-use change & $\begin{array}{l}\text { Global (climate } \\
\text { change mitigation) }\end{array}$ & $\begin{array}{l}\text { Million } \\
\text { hectares }\end{array}$ & 1 & 6 & 2020 & FAO (2020) \\
\hline $\begin{array}{l}\text { Net change in leaf area } \\
(2000-2017)\end{array}$ & $\begin{array}{l}\text { Climate change } \\
\text { mitigation }\end{array}$ & Global & $\%$ & 1 & 2 & 2017 & Chen et al. (2019) \\
\hline Electric car market shares & $\begin{array}{l}\text { Climate change } \\
\text { mitigation }\end{array}$ & Global & $\%$ & 13 & 28 & 2020 & IEA (2021) \\
\hline $\begin{array}{l}\text { Wind electricity } \\
\text { generation }\end{array}$ & $\begin{array}{l}\text { Climate change } \\
\text { mitigation }\end{array}$ & Global & GWh & 1 & 4 & 2018 & IEA (2020) \\
\hline $\begin{array}{l}\text { Solar PV electricity } \\
\text { generation }\end{array}$ & $\begin{array}{l}\text { Climate change } \\
\text { mitigation }\end{array}$ & Global & GWh & 1 & 5 & 2018 & IEA (2020) \\
\hline
\end{tabular}


China and India have also developed their own novel climate change policies that have domestic and international implications. Chinese President Jinping $\mathrm{Xi}$ announced in September 2020 ambitious long-term goals of carbon neutrality by 2060 , as well as reaching peak levels of admissions by 2030 (Maizland 2021). An example of India's leadership in sustainable energy is the International Solar Alliance (ISA; https://isolaralliance.org/), launched in November 2015 by India's Premier, Narendra Modi, and the former French President, Francois Hollande, which promises to cover 121 tropical nations (Shidore and Busby 2019). India also recently announced plans that it would meet $50 \%$ of its energy requirements from renewable energy by 2030, and be carbon neutral by 2070 (MEA 2021).

Both countries have also made progress in the field of biodiversity conservation, ensuring continued ecosystem services. China has invested heavily in restoration projects that have brought benefits in increased forest cover and reduced soil erosion, among other metrics, although there has been less success in restoring biodiversity (Hua et al. 2016; Ouyang et al. 2016; Liu et al. 2018). This strategy includes compensating those affected by conservation policies, and incentivizing environmentallyfriendly decisions (Shang et al. 2018). China has also expanded its protected areas (PA) system rapidly, reaching $18 \%$ of the land cover (Li and Pimm 2020); still PAs do not include many areas with the highest biodiversity and ecosystem services (Xu et al. 2017). India's PA system, which has been in place for a longer period of time, covers only $7.5 \%$ of the country (https://www. protectedplanet.net/country/IND), yet has suffered no documented species extinctions in 70 years, despite there often being high levels of human presence in PAs (GhoshHarihar et al. 2019). There are plans to undertake a National Mission on Biodiversity and Human Wellbeing (Bawa et al. 2020b), although funding for these ambitious programs is yet to mature. A further strength for biodiversity conservation in India comes from its legal system: India's policy on environmental protection mandates that all major infrastructure development projects include environmental management plans as part of their environmental impact assessment reports (Paliwal 2006). These development projects provide large funding support to state forest departments and civil society groups. For instance, the hydropower companies building power projects on Himalayan rivers may earmark about USD 13 million per 100 megawatt installed capacity for environmental protection and conservation activities (M. K. Pandit, unpublished data).

As to water resources and pollution safeguards, the countries' policies and successes may reflect their different systems of governance and economic realities.
China has put a lot of investment into pollution control in the past decade, with tangible results (e.g., reduction in PM2.5, Xiao et al. 2020). A comparison between the two countries in water governance concluded that China may have been more successful in providing water and sanitation over the past decades (Araral and Ratra 2016), although a recent study shows improvement in India since the announcement of the SDGs, and India gearing their policies towards SDG realization (Ahmed and Araral 2019). The authors attribute some of the differences in the success of water policy between the two countries to China's greater economic development and its more centralized form of government in this sphere, compared to the Indian system that is led at the state-level and has many different institutions having veto power over each other (Araral and Ratra 2016). This example reminds us that similar problems in the two countries may require very different solutions, based on different economic situations and mechanisms of government. Nevertheless, sharing of information about the severity of the problems, and quantitative assessments of technological and policy solutions, gives policy-makers in both countries a greater range of options.

\section{PATTERNS OF COLLABORATION: CO- AUTHORSHIP AND FUNDING ANALYSES}

To gauge the current level of collaboration between the two countries, we acquired bibliographic information on coauthorship between institutions in different countries in the environmental sciences. Co-authorship is but one metric to gauge collaboration, and cannot detect diplomatic ties and collaborative economic projects that may not result in a research paper. Yet co-authorship does seem an appropriate measuring stick, considering that both countries have pushed to internationalize their institutes of higher education, particularly valuing research articles published in English (Li et al. 2012; Jöns and Hoyler 2013; Rajan et al. 2018). We selected a total of 20000 articles from journals in English in the CrossRef database (https://www.crossref. org/) that concentrated on agriculture, conservation, ecology, environmental science, and global change, published between 2015 and 2018 .

We found that most Asian countries had their most intense research connections to non-Asian research hubs such as the United States and several Western European countries, with few connections among Asian countries (Fig. 1). Indeed, both China and India have long favored collaborating with international experts who are renown in their field, and located in historically developed and wellfunded countries on other continents (Jöns and Hoyler 2013). The interaction between China and India was 


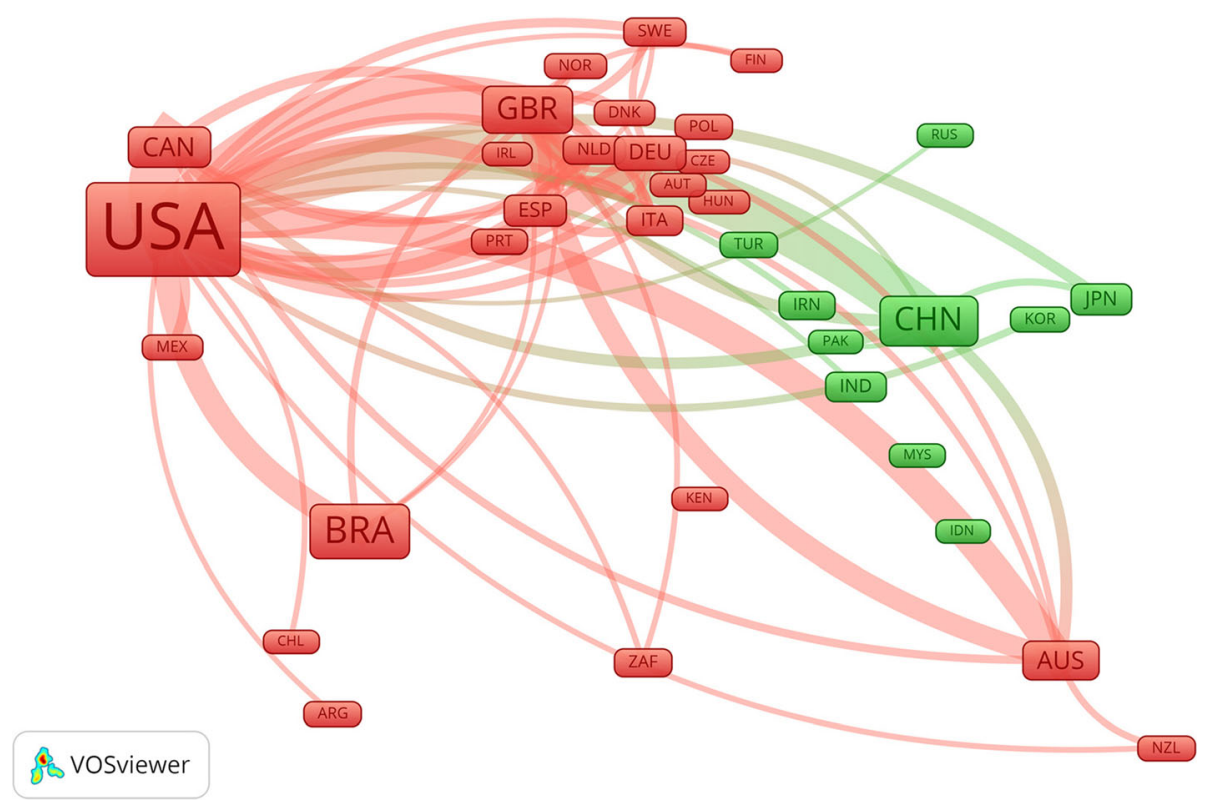

Fig. 1 A network map showing co-authorship patterns between countries in the environmental science based on 20000 articles published in English between 2015 and 2018. Asian countries are shown in green, and other countries in red; the size of label is proportional to the number of research articles a country produced. Countries are shown if they were included in at least 175 publications, and links between countries are shown if there were at least 50 co-authorships. The lack of connection between China (CHN) and India (IND) was strongly significant (see text)

particularly lacking, despite both being separately productive (at least one author with a Chinese institutional address was present in 2021 articles; Indian authors were similarly represented in 537 articles). The two countries were included in the authorship team together in only eight articles (and only five in which one of the countries held corresponding authorship), compared to an expected cooccurrence based on their productivity of 25.3 articles $(P<0.009)$. This deviation from random expectations was the largest such deviation between any two Asian countries in the dataset.

This pattern of lack of co-authorship between China and India has been found across disciplines since the 1990s (Gupta and Dhawan 2003), but the current environment brings both new challenges and opportunities. In terms of higher education, in 2019 some new restrictions were placed on collaboration between universities in the two countries, and it was reported that there have been no official scientific exchanges between the national academies of the two countries over the previous two years (Kumar 2019). Yet within the same time period, institutional collaborations like those supported by the "Scheme for Promotion of Academic and Research Collaboration" of the Indian Ministry of Education have encouraged cooperation with Chinese universities, and more Indian students have begun to look to China for higher educational opportunities (Feng and Garg 2021). In terms of broader societal trends, the pattern of non-collaboration is surely influenced by the different political alliances of the countries; for example, India is not a participant in the Belt and Road Initiative (Huang 2016). Yet the two countries regularly interact in various alliances such as BRICS (infobrics.org) and the Shanghai Cooperation Organization (SCO; http://sectsco.org/). Importantly, the two countries are very highly connected economically, with China currently being India's second-largest trading partner (PTI 2020). A good example of the mutual economic dependence of the two countries is that while India proudly describes itself as the 'world's pharmacy', it imports about $70 \%$ of its active pharmaceutical ingredients from China (Mukul et al. 2020). Given the interconnection between economic development and environmental degradation, particularly for middle-income countries with rapid growth (Stern 2004; Mills and Waite 2009; Dahlman 2012), both countries need to balance their intertwined growth with coordinated action on the environment.

The limited nature of collaboration between China and India notwithstanding, overall scientific funding in the countries, including that for the environmental sciences, has strongly increased over the past ten years. Because the information in the annual reports of the various institutions changed over time, and they differed in the information reported, it was not possible to measure specifically environmental funding for the majority of institutions, and thus we focus on their overall budgets. We also limit the analysis to before the COVID-19 pandemic, which has brought new financial constraints and priorities. We found the budgets of six large Chinese and Indian scientific funders 
increased an average of 2.1 times between 2010 and 2018, when judged in their own currencies (Fig. 2). Again, specific information on international collaboration grants was not available for most funders. However, for the National Natural Science Foundation of China (NNSFC), funding for international collaboration increased 3.25 times (16 600 000 RMB in 2010 [ \$2 452 000], versus 54000000 in 2018 [ $\$ 8178000]$ ). With such increased funding may come greater ability to select which international partners the researchers want to collaborate with.

\section{ON WHAT ISSUES SHOULD COLLABORATION BETWEEN THE COUNTRIES FOCUS?}

Given the obstacles for collaboration between China and India, in this section we will encourage not only joint research (i.e., collaboration), but also coordination-

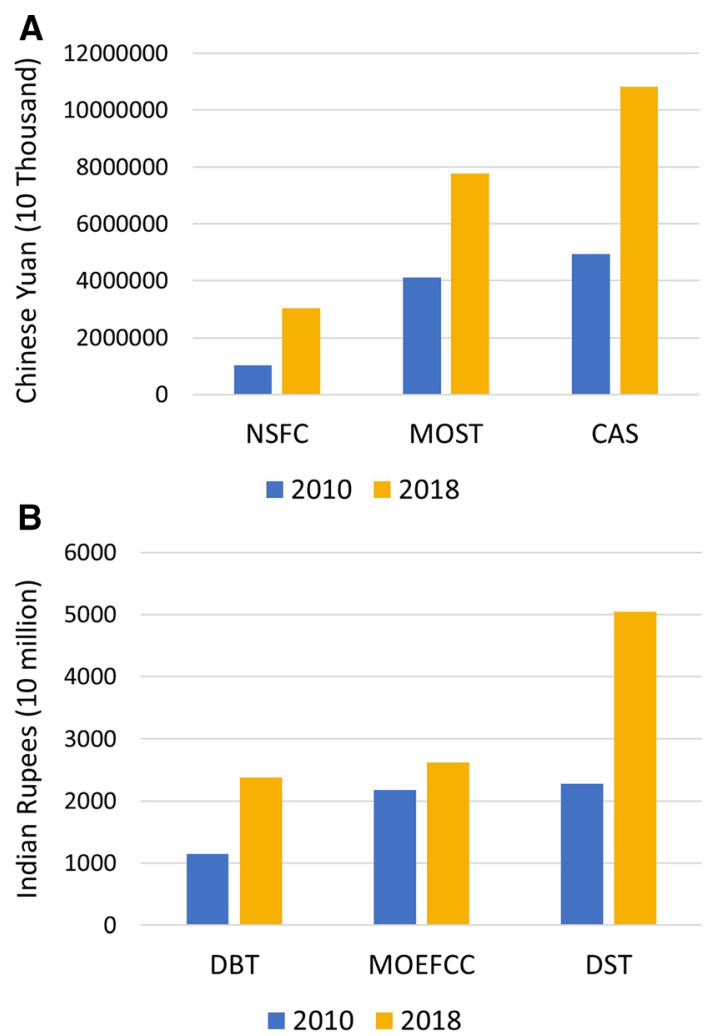

Fig. 2 The total organizational budgets of major scientific funders in the two countries over an eight-year period. Chinese budgets (panel A) are from the 2010 and 2018 annual years, Indian budgets (panel B) are from the 2010-2011 and 2018-2019 years; all figures represent actual expenditures. CAS Chinese Academy of Sciences (https:// www.cas.cn/), MOST Ministry of Science and Technology (https:// www.most.gov.cn), NSFC National Science Foundation of China (https://nsfc.gov.cn/); DBT Department of Biotechnology (https:// dbtindia.gov.in/), DST Department of Science and Technology (https://dst.gov.in/), MOEFCC Ministry of Environment, Forestry and Climate Change (https://moef.gov.in/) unilateral research within each country, but with an appreciation for what the other country is working on and has accomplished. We stress that while such collaboration can involve aspects that could lead to economic development, plans should include provisions so that environmental degradation is not simultaneously increased (as also argued by Lechner et al. 2018). While we acknowledge that pure research does not by itself produce changes in environmental behavior, it can provide the knowledge base and policy recommendations to act on, especially if researchers publicize their findings widely and engage with policy makers (Arlettaz et al. 2010; Harris and Lyon 2013). Given the differences between the strategies that the two countries have had success with, there is a critical opportunity for them to learn from each other.

Returning to the region of the border conflict, the shared Himalaya represents a foundation and starting point for the countries' collaboration (Bawa et al. 2010, Table 2). The region includes four biodiversity hotspots (Xu et al. 2019), yet is threatened by hydroelectric power projects and climate change (Pandit 2017). Indeed, the desolate high-elevation landscape along the Himalayan borders might be best suited as a peace park (Bawa et al. 2020a) or series of nature reserves and thereby a part of "conservation diplomacy" (Pandit 2020). The Himalaya offer vast opportunities of collaborative research on biodiversity, for the two regions share geological and evolutionary history (Pandit 2017). Institutions on both sides of the border would benefit from organizing joint research connections, as has been started between the Kunming Institute of Botany and the Balipara Foundation in Guwahati (NortheastNow News 2018) to promote climate change research and the discovery of new forms of biodiversity (e.g., Karunarathna et al. 2020). Research on migrating animals, particularly birds and mammals, and on the evolutionary history of biodiversity of the region, would be other fitting subjects of collaborative research. Links between scientists can be a form of non-official "scientific diplomacy" that longterm engenders trust and a positive atmosphere for collaboration (Shrestha and Bhadra 2019). At a regional level, the International Centre for Integrated Mountain Development (ICIMOD; https://www.icimod.org/), the inter-governmental organization based in Nepal that includes both China and India and six other Himalayan neighbors, has and will continue to be an important forum for collaboration between the countries for both science and policy development. The "Hindu Kush Himalaya assessment: Mountains, climate change, sustainability and people" (Wester et al. 2019), coordinated by ICIMOD, serves as an excellent starting point to understand the region's environmental problems and potential pathways forward. ICIMOD has also implemented transboundary projects, such as the "Kailash Sacred Landscape Conservation and 
Development Initiative" project (ICIMOD 2019), which worked in China, India and Nepal.

Beyond the Himalaya, the shared environmental challenges summarized here (Table 1) represent an important justification for a longer-term broadening of collaborative efforts (Table 2). From the perspective of understanding how human health is affected by toxic compounds, the two countries have large populations with different genetic backgrounds that are exposed to high levels of pollution. The same threats also affect biodiversity and ecosystems; the vast expanses of the countries hold an array of habitat types, yet the biodiversity shares evolutionary history, often being related at the species, generic or family level. Crops, pests, disease agents and catchment areas are also shared; hence food and water security and disaster mitigation, such as from dams and floods and climate change, should be key areas for coordination, data and information sharing, and collaboration.

The study of mercury pollution serves as a specific example for why collaboration between China and India needs to be strengthened. Mercury $(\mathrm{Hg})$ is a neurotoxin, ranked among the most toxic substances in the world, and for which an international treaty has been formulated to control its emission (Driscoll et al. 2013). The exposure route for much of the developed world, and specifically in North America and Europe, has been through aquatic sources (due to anoxic conditions) and particularly fishconsumption both for humans and for wildlife. However, recent work from non-coastal China has shown that rice (also grown in anoxic conditions) may be the primary route of $\mathrm{Hg}$ exposure for humans (Zhang et al. 2010) and wildlife (Abeysinghe et al. 2017). As rice is a dominant crop in Asia, particularly in China and India, there is likely a regional pattern of dissemination and exposure to this toxin, quite distinct from other parts of the world. China and India would be wise to explore the implications of this regional pattern together, rather than primarily collaborating with the United States and Europe, for both countries currently have the required testing facilities and trained researchers to do so. For India, as its emissions rise, there is a particular need and opportunity to work with China on this issue, both in understanding the effects of $\mathrm{Hg}$ and planning mitigation efforts. At the same time, China has a stake in working with India, as atmospheric deposition from India can end up across the Himalayan borders, including the Tibetan Plateau, the source of much freshwater for these two countries and their neighbors (Huang et al. 2020; Sun et al. 2020). In summary, Hg illustrates how many environmental problems have regional patterns that may be best addressed by neighbors collaboratively. China and India should particularly engage with each other as they also share problems associated with being vast countries with large human populations.

Recognition of these commonalities continues to bring scientists in both countries together at the bilateral governmental, regional intergovernmental, and individual institution/scientist levels (Table 2). Some of these interactions have come under the auspices of the economic meetings of the countries. For example, at the Sixth ChinaIndia Strategic Economic Dialogue the two countries agreed to further cooperate to promote the circular economy (Xia 2019), and the BRIC Science Academic Committee has organized a report that highlights the critical importance of mountain ecosystems and biodiversity (M. K. Pandit, personal communication). Regional organizations like ICIMOD can bring scientists from the two countries together, analogous to the way that the Arctic Council has brought together countries and scientists concerned about toxins accumulating in the northern parts of the world (https://www.amap.no/). Finally, other meetings have been self-organized by scientists. For example, both countries have hosted meetings of the "Asian Air Pollution

Table 2 Issues to study, and kinds of organizers, for collaboration between China and India in the environmental sciences, with some successful examples, and some potential pathways forward

Issue 1. Research in the Himalaya region

1.a. Organizers: Regional organizations, such as the International Centre for Integrated Mountain Development (ICIMOD), and its "Kailash Sacred Landscape Conservation and Development Initiative"

1.b. Organizers: Institutions or scientists, such as the collaboration between Balipara Foundation (India) and the Kunming Institute for Botany, Chinese Academy of Sciences (China)

Issue 2. Research on the wider issues of environmental problems shared between the countries

2.a. Organizers: Working groups associated with bilateral meetings (e.g., China-India Strategic Economic Dialogue) or intergovernmental organizations (e.g., BRICS, Shanghai Cooperation Organization)

2.b. Organizers: Regional organizations (such as ICIMOD and its "Atmosphere" unit) could potentially leverage their knowledge to address larger issues throughout both countries (e.g., air pollution), analogous to the role the Arctic Council has done in ecotoxicological studies

2.c. Organizers: Scientists or societies, such as "Asian Air Pollution Workshop", International Union of Forest Research Organizations'

"Working Unit 8.04 on Air Pollution and Climate Changes' Effects on Forest Ecosystems", and the "First Indo-China Research Series in Geotechnical and Geoenvironmental Engineering", who or which could be potentially facilitated by the development of a joint China/India funding mechanism 
Workshop" and the International Union of Forest Research Organizations' "Working Unit 8.04 on Air Pollution and Climate Changes' Effects on Forest Ecosystems". Recently during the COVID-19 pandemic, organizers of the "First Indo-China Research Series in Geotechnical and Geoenvironmental Engineering" held their meeting entirely online, including 128 presentations and $\sim 5000$ participants (Feng and Garg 2021). These examples demonstrate the critical role scientists can play to bridge the gap between the two countries. We suggest that a way in which the governments of the countries could encourage the formation of scientist teams is through a joint funding program, such as those between China and the United States, both in biodiversity research (https://beta.nsf.gov/ funding/opportunities/dimensions-biodiversity) and sustainability (https://nsf.gov/pubs/2021/nsf21103/nsf21103. jsp).

\section{CONCLUSIONS}

The COVID-19 pandemic has further highlighted human vulnerability to environmental disasters while reinforcing the belief that collaboration and coordination will be the key to resolving this century's pressing interrelated challenges to public health, food security, climate change, and loss of biodiversity and ecosystem services. As China and India increase their investment in higher education and environmental sciences research and technology development, interactions need not be limited to partners on different continents that have traditionally strong university and funding infrastructure (e.g., the ubiquitous cross-continental collaborations illustrated in Fig. 1). Rather, regional partners and neighbors should be chosen that share problems to strengthen problem-solving. We encourage not only collaboration on joint projects, but also coordination that comes simply from being aware of the other country's successes and failures in the environmental arena.

The agenda for collaboration/coordination between the two countries could start with the shared Himalaya, where personal and institutional linkages can facilitate diplomacy. We then envision a broadening of interactions around issues of shared environmental threats and solutions. The identification of shared interests is just the beginning of the process of international collaboration, which also must include acknowledging inequalities, such as lesser funding for research in India, and apportioning responsibilities and benefits (Perz et al. 2010; Parker and Kingori 2016). Scientists should lead this process, whether it is through governmental channels, academic and research institutions or NGOs, or on the sidelines of international meetings (Table 2). Such exchanges can lead to increased opportunities for a sustainable and peaceful world.
Acknowledgements We are thankful for the suggestions of Mesfin Mekonnen, Kartik Shanker, Hari Sridhar and Frits Steenhuisen about data sources, the helpful discussions with Madhoolika Agrawal, Alessandra Demarco, Zhaozhong Feng, Janita Gurung, and Vincent Nijman, and the constructive criticism of two anonymous reviewers. EG, UMG, AJ, CM, MM and K-FC would like to acknowledge the support of Guangxi University, UMG is grateful for the support of the Guangxi Overseas High-Level 100 People Program, AJ is thankful for a Key Grant of Guangxi Nature and Science Foundation (2018GXNSFDA281016), JL is supported by the U.S. National Science Foundation (1924111) and Michigan AgBioResearch, and K-FC appreciates funding from the Bagui Scholarship of Guangxi Zhuang Autonomous Region (C33600992001).

Author contributions EG organized the project and led writing, $\mathrm{CM}, \mathrm{WM}$ and Y-FC led data collection and analysis, and all authors contributed to discussion, writing and editing.

\section{Declarations}

Conflict of interest The authors declare that they have no conflict of interest.

\section{REFERENCES}

Aas, W., A. Mortier, V. Bowersox, R. Cherian, G. Faluvegi, H. Fagerli, J. Hand, Z. Klimont, et al. 2019. Global and regional trends of atmospheric sulfur. Scientific Reports 9: 1-11.

Abeysinghe, K.S., G. Qiu, E. Goodale, C.W.N. Anderson, K. Bishop, D.C. Evers, M.W. Goodale, H. Hintelmann, et al. 2017. Mercury flow through an Asian rice-based food web. Environmental Pollution 229: 219-228.

Ackerman, D., D. Millet, and X. Chen. 2019. Global estimates of inorganic nitrogen deposition across four decades. Global Biogeochemical Cycles 33: 100-107.

Ahmed, M., and E. Araral. 2019. Water governance in India: Evidence on water law, policy, and administration from eight Indian states. Water 11: 2071.

AMAP, UN Environment. 2019. Technical background report for the global mercury assessment. Oslo/Geneva: Arctic Monitoring and Assessment Programme/UN Environment Programme. Available at: https://www.unep.org/resources/publication/globalmercury-assessment-technical-background-report.

Araral, E., and S. Ratra. 2016. Water governance in India and China: Comparison of water law, policy and administration. Water Policy 18: 14-31.

Arlettaz, R., M. Schaub, J. Fournier, T.S. Reichlin, A. Sierro, J.E.M Watson, and V. Braunisch. 2010. From publications to public actions: When conservation biologists bridge the gap between research and implementation. BioScience 60: 835-842.

Baldé, C., V. Forti, V. Gray, R. Kuehr, and P. Stegmann. 2017. The Global E-waste Monitor-2017: Quantities, flows and resources. Bonn/Geneva/Vienna: United Nations University, International Telecommunication Union \& International Solid Waste Association. Available at: https://ewastemonitor.info/gem-2017/.

Bawa, K.S., E. Goodale, W. Mtemi, Y. Chen, R. Barthakur, U.M. Goodale, A. Jiang, J. Liu, et al. 2020a. China and India: Toward a sustainable world. Science 369: 515.

Bawa, K.S., L.P. Koh, T.M. Lee, J. Liu, P. Ramakrishnan, W.Y. Douglas, Y.-P. Zhang, and P.H. Raven. 2010. China, India, and the environment. Science 327: 1457-1459.

Bawa, K.S., N. Nawn, R. Chellam, J. Krishnaswamy, V. Mathur, S.B. Olsson, N. Pandit, P. Rajagopal, et al. 2020b. Envisioning a 
biodiversity science for sustaining human well-being. Proceedings of the National Academy of Sciences 117: 25951-25955.

Chen, C., T. Park, X. Wang, S. Piao, B. Xu, R.K. Chaturvedi, R. Fuchs, V. Brovkin, et al. 2019. China and India lead in greening of the world through land-use management. Nature Sustainability 2: $122-129$.

DAC\&FW. 2019. Commodity Profile for Edible Oil for September. New Delhi: Department of Agriculture, Cooperation and Farmers Welfare (DAC\&FW). Available at: https://www.agricoop. gov.in/sites/default/files/Edible-oil-Profile-21-11-2019.pdf.

Dahlman, C. 2012. The world under pressure: How China and India are influencing the global economy and environment. Palo Alto, CA: Stanford University Press.

Driscoll, C.T., R.P. Mason, H.M. Chan, D.J. Jacob, and N. Pirrone. 2013. Mercury as a global pollutant: Sources, pathways, and effects. Environmental Science and Technology 47: 4967-4983.

FAO. 2018. Global forest products: Facts and figures. Rome: Food and Agriculture Organization (FAO) of the United Nations. Available at: https://www.fao.org/forestry/statistics.

FAO. 2020. Global Forest Resources Assessment 2020: Main report. Rome: Food and Agriculture Organization of the United Nations (FAO). Available at: https://www.fao.org/documents/card/en/c/ ca9825en.

Feng, D. H., and A. Garg. 2021. India and China scientific collaborations at grass-root level: A new era. In: Proceedings of the 1st Indo-China Research Series in Geotechnical and Geoenvironmental Engineering, 175-194. Singapore: Springer.

Fiedler, H., R. Kallenborn, J. de Boer, and L.K. Sydnes. 2019. The Stockholm convention: A tool for the global regulation of persistent organic pollutants. Chemistry International 41: 4-11.

Gackstatter, S., M. Kotzemir, and D. Meissner. 2014. Building an innovation-driven economy-The case of BRIC and GCC countries. Foresight 16: 293-308.

Ghosh-Harihar, M., R. An, R. Athreya, U. Borthakur, P. Chanchani, D. Chetry, A. Datta, A. Harihar, et al. 2019. Protected areas and biodiversity conservation in India. Biological Conservation 237: 114-124.

Goldman, R. 2020. Indian-China border dispute: A conflict explained. New York, NY: New York Times. Available at: https://www. nytimes.com/2020/06/17/world/asia/india-china-border-clashes. html.

Gupta, B., and S. Dhawan. 2003. India's collaboration with People's Republic of China in science and technology: A scientometric analysis of coauthored papers during 1994-1999. Scientometrics 57: 59-74.

Harris, F., and F. Lyon. 2013. Transdisciplinary environmental research: Building trust across professional cultures. Environmental Science and Policy 31: 109-119.

Hua, F., X. Wang, X. Zheng, B. Fisher, L. Wang, J. Zhu, Y. Tang, D.W. Yu, et al. 2016. Opportunities for biodiversity gains under the world's largest reforestation programme. Nature Communications 7: 12717.

Huang, J., S.C. Kang, R.S. Yin, M. Lin, J.M. Guo, K. Ram, C.L. Li, C. Sharma, et al. 2020. Decoupling natural and anthropogenic mercury and lead transport from South Asia to the Himalayas. Environmental Science and Technology 54: 5429-5436.

Huang, Y.P. 2016. Understanding China's Belt \& Road Initiative: Motivation, framework and assessment. China Economic Review 40: 314-321.

ICIMOD. 2019. Kailash Sacred Landscape Conservation and Development Initiative: Phase I Report 2012-2017. Katmandu: International Centre for Integrated Mountain Development (ICIMOD). Available at: https://lib.icimod.org/record/34707.

IEA. 2020. Renewables information. Paris: International Energy Agency (IEA). Available at: https://www.iea.org/reports/ renewables-2020.
IEA. 2021. Global electric vehicle (EV) data explorer. Paris: International Energy Agency (IEA). Available at: https://www. iea.org/articles/global-ev-data-explorer.

India State-Level Disease Burden Initiative Air Pollution Collaborators. 2019. The impact of air pollution on deaths, disease burden, and life expectancy across the states of India: The Global Burden of Disease Study 2017. The Lancet Planetary Health 3: e26-e39.

Jöns, H., and M. Hoyler. 2013. Global geographies of higher education: The perspective of world university rankings. Geoforum 46: 45-59.

Karakır, İA. 2018. Environmental foreign policy as a soft power instrument: Cases of China and India. Journal of Contemporary Eastern Asia 17: 5-26.

Kark, S., N. Levin, H.S. Grantham, and H.P. Possingham. 2009. Between-country collaboration and consideration of costs increase conservation planning efficiency in the Mediterranean Basin. Proceedings of the National Academy of Sciences 106: 15368-15373.

Karunarathna, S.C., P.E. Mortimer, S. Tibpromma, A.K. Dutta, S. Paloi, Y. Hu, G. Baurah, S. Axford, et al. 2020. Roridomyces phyllostachydis (Agaricales, Mycenaceae), a new bioluminescent fungus from Northeast India. Phytotaxa 459: 155-167.

Kumar, S. 2019. Indian government tightens rules on academic collaboration with China. Science. Available at: https://www. sciencemag.org/news/2019/10/indian-government-tightensrules-academic-collaboration-china.

Lebreton, L., and A. Andrady. 2019. Future scenarios of global plastic waste generation and disposal. Palgrave Communications 5: $1-11$.

Lechner, A.M., F.K.S. Chan, and A. Campos-Arceiz. 2018. Biodiversity conservation should be a core value of China's Belt and Road Initiative. Nature Ecology and Evolution 2: 408-409.

Li, B.V., and S.L. Pimm. 2020. How China expanded its protected areas to conserve biodiversity. Current Biology 30: R1334R1340.

Li, C., C. McLinden, V. Fioletov, N. Krotkov, S. Carn, J. Joiner, D. Streets, H. He, et al. 2017. India is overtaking China as the world's largest emitter of anthropogenic sulfur dioxide. Scientific Reports 7: 14304.

Li, Y.A., J. Whalley, S. Zhang, and X. Zhao. 2012. The higher educational transformation of China and its global implications. In The globalization of higher education, ed. C.T. Ennew and D. Greenaway, 135-162. New York: Palgrave MacMillan.

Liu, J. 2018. An integrated framework for achieving sustainable development goals around the world. Ecology, Economy and Society: The INSEE Journal 1: 11-17.

Liu, J., and J. Diamond. 2005. China's environment in a globalizing world. Nature 435: 1179-1186.

Liu, J.G., A. Vina, W. Yang, S.X. Li, W.H. Xu, and H. Zheng. 2018. China's environment on a metacoupled planet. Annual Review of Environment and Resources 43: 1-34.

Maizland, L. 2021. China's fight against climate change and environmental degradation. Council on Foreign Relations. Available at: https://www.cfr.org/backgrounder/china-climatechange-policies-environmental-degradation.

Mammides, C., E. Goodale, M. Elleason, and R.T. Corlett. 2021. Designing an ecologically representative global network of protected areas requires transboundary coordination between countries. Environmental Research Letters 16: 121001.

Mason, N., M. Ward, J.E. Watson, O. Venter, and R.K. Runting. 2020. Global opportunities and challenges for transboundary conservation. Nature Ecology and Evolution 4: 694-701.

MEA. 2021. National Statement by Prime Minister Shri Narendra Modi at COP26 Summit in Glasgow (November 2, 2021). New Dehli: Ministry of External Affairs (MEA). Available at: https:// www.mea.gov.in/Speeches-Statements.htm?dt1/34466/National+ 
Statement + by + Prime + Minister + Shri + Narendra + Modi + at + COP26+Summit+in+Glasgow.

Mekonnen, M. M., and A. Y. Hoekstra. 2016. Four billion people facing severe water scarcity. Science Advances 2: e1500323.

Mills, J.H., and T.A. Waite. 2009. Economic prosperity, biodiversity conservation, and the environmental Kuznets curve. Ecological Economics 68: 2087-2095.

Mittermeier, R.A., P.R. Gil, M. Hoffman, J. Pilgram, T. Brooks, C.G. Mittermeier, J. Lamoreux, and G.A.B. da Fonseca. 2004. Hotspots revisited: Earth's biologically richest and most endangered terrestrial ecosystems. Mexico City: CEMEX.

Mittermeier, R.A., and C.G. Mittermeier. 1997. Megadiversity: Earth's biologically wealthiest nations. Mexico, D.F.: CEMEX.

Mukul, P., P. Raghavan, and A. Bhatia. 2020. Stopping China imports may hurt India's edge, exports: Telcos, pharma companies. New Delhi: Indian Express.

NortheastNow News. 2018. India and China join hands for community conservation. Guwahati: NorthEastNow News. Available at: https://nenow.in/north-east-news/assam/india-china-join-handscommunity-conservation.html.

Ouyang, Z., H. Zheng, Y. Xiao, S. Polasky, J. Liu, W. Xu, Q. Wang, L. Zhang, et al. 2016. Improvements in ecosystem services from investments in natural capital. Science 352: 1455-1459.

Paliwal, R. 2006. EIA practice in India and its evaluation using SWOT analysis. Environmental Impact Assessment Review 26: 492-510.

Pandit, M.K. 2017. Life in the Himalaya: An Ecosystem at Risk. Cambridge, MA, USA: Harvard University Press.

Pandit, M.K. 2020. The Himalaya should be a nature reserve. Nature 583: 9.

Parker, M., and P. Kingori. 2016. Good and bad research collaborations: Researchers' views on science and ethics in global health research. PLOS ONE 11: e0163579.

Perz, S.G., S. Brilhante, I.F. Brown, A.C. Michaelsen, E. Mendoza, V. Passos, R. Pinedo, J.F. Reyes, et al. 2010. Crossing boundaries for environmental science and management: Combining interdisciplinary, interorganizational and international collaboration. Environmental Conservation 37: 419-431.

PTI. 2020. US remains India's top trading partner in 2019-20. The Economic Times, New Delhi, India; as reported by the Press Trust of India (PTI). Available at: https://economictimes. indiatimes.com/news/economy/foreign-trade/u-s-remains-indiastop-trading-partner-in-2019-20/articleshow/76924711.cms.

Rajan, K., S. Swaminathan, and S. Vaidhyasubramaniam. 2018. Research output of Indian institutions during 2011-2016: Quality and quantity perspective. Current Science 114: 740-746.

Ramanathan, V., C. Chung, D. Kim, T. Bettge, L. Buja, J. Kiehl, W. Washington, Q. Fu, et al. 2005. Atmospheric brown clouds: Impacts on South Asian climate and hydrological cycle. Proceedings of the National Academy of Sciences 102: 5326-5333.

Shang, W., Y. Gong, Z. Wang, and M.J. Stewardson. 2018. Ecocompensation in China: Theory, practices and suggestions for the future. Journal of Environmental Management 210: $162-170$

Shidore, S., and J.W. Busby. 2019. One more try: The International Solar Alliance and India's search for geopolitical influence. Energy Strategy Reviews 26: 100385.

Shrestha, U.B., and A. Bhadra. 2019. Science in South Asia. Science 364: 1211

Solomon, S., D.J. Ivy, D. Kinnison, M.J. Mills, R.R. Neely, and A. Schmidt. 2016. Emergence of healing in the Antarctic ozone layer. Science 353: 269-274.

Steffen, W., K. Richardson, J. Rockstrom, S.E. Cornell, I. Fetzer, E.M. Bennett, R. Biggs, S.R. Carpenter Wim, et al. 2015.
Planetary boundaries: Guiding human development on a changing planet. Science 347: 1259855.

Stern, D.I. 2004. The rise and fall of the environmental Kuznets curve. World Development 32: 1419-1439.

Sun, X., Q. Zhang, M. Li, K. Kandel, B. Rawat, A. Pandey, J. Guo, S. Kang, et al. 2020. Mercury variation and export in transHimalayan rivers: Insights from field observations in the Koshi River. Science of the Total Environment 738: 139836.

Wester, P., A. Mishra, A. Mukherji, and A.B. Shrestha, eds. 2019. The Hindu Kush Himalaya assessment: Mountains, climate change, sustainability and people. Cham: Springer. Available at: https:// link.springer.com/book/10.1007/978-3-319-92288-1.

Xia, L. 2019. China, India vow to deepen cooperation at 6th Strategic Economic Dialogue held in India. Beijing: Xinhua. Available at: http://www.xinhuanet.com/english/special/2019-09/10/c_138380 768.htm.

Xiao, Q., G. Geng, F. Liang, X. Wang, Z. Lv, Y. Lei, X. Huang, Q. Zhang, et al. 2020. Changes in spatial patterns of PM2.5 pollution in China 2000-2018: Impact of clean air policies. Environment International 141: 105776.

Xu, J., R. Badola, N. Chettri, R.P. Chaudhary, R. Zomer, B. Pokhrel, S.A. Hussain, S. Pradhan, et al. 2019. Sustaining biodiversity and ecosystem services in the Hindu Kush Himalaya. In The Hindu Kush Himalaya assessment: Mountains, climate change, sustainability and people, ed. P. Wester, A. Mishra, A. Mukherji, and A.B. Shrestha, 127-165. Cham: Springer.

Xu, W., Y. Xiao, J. Zhang, W. Yang, L. Zhang, V. Hull, Z. Wang, H. Zheng, et al. 2017. Strengthening protected areas for biodiversity and ecosystem services in China. Proceedings of the National Academy of Sciences of the United States of America 114: 1601-1606.

Zhang, H., X. Feng, T. Larssen, G. Qiu, and R.D. Vogt. 2010. In inland China, rice, rather than fish, is the major pathway for methylmercury exposure. Environmental Health Perspectives 118: $1183-1188$.

Publisher's Note Springer Nature remains neutral with regard to jurisdictional claims in published maps and institutional affiliations.

\section{AUTHOR BIOGRAPHIES}

Eben Goodale is a Professor at the College of Forestry, Guangxi University. His research focus is in behavioral and community ecology and conservation biology, but he is increasingly interested in conservation issues that center on humans.

Address: Guangxi Key Laboratory of Forest Ecology and Conservation, College of Forestry, Guangxi University, Daxuedonglu 100, Nanning 530004, Guangxi, China.

e-mail: ebengoodale@gxu.edu.cn; eben.goodale@outlook.com

Christos Mammides is a conservation scientist interested in using statistical and spatial tools to understand anthropogenic impact on biodiversity. Christos is currently affiliated with the Nature Conservation Unit of Frederick University in Cyprus.

Address: Guangxi Key Laboratory of Forest Ecology and Conservation, College of Forestry, Guangxi University, Daxuedonglu 100, Nanning 530004, Guangxi, China.

Address: Nature Conservation Unit, Frederick University, 7, Yianni Frederickou Street, Pallouriotissa, 1036 Nicosia, Cyprus.

e-mail: cmammides@outlook.com

Wambura Mtemi is a doctoral student at the College of Forestry, Guangxi University, interested in ecotoxicology.

Address: Guangxi Key Laboratory of Forest Ecology and 
Conservation, College of Forestry, Guangxi University, Daxuedonglu 100, Nanning 530004, Guangxi, China.

e-mail:wmashauri@outlook.com

You-Fang Chen is finishing her Master of Science degree at Guangxi University. In her thesis she has explored how acoustic indices can detect biodiversity and environmental conditions.

Address: Guangxi Key Laboratory of Forest Ecology and Conservation, College of Forestry, Guangxi University, Daxuedonglu 100, Nanning 530004, Guangxi, China.

e-mail: 1215810189@qq.com

Ranjit Barthakur is the Founder of the Balipara Foundation, where he drives community-based conservation and livelihoods in the Eastern Himalayas through cutting edge proprietary concepts such as Naturenomics and Rural Futures for sustainable social change and thriving habitats.

Address: Balipara Foundation, A1 Navin Enclave, Mother Teresa Road, Guwahati, Assam 781021, India.

e-mail: ranjit.barthakur@baliparafoundation.com

Uromi Manage Goodale is an Associate Professor at the College of Forestry, Guangxi University, Editor-in-Chief of the Journal of Sustainable Forestry and the Co-Chair of the Seed Conservation Specialist Group, Species Survival Commission of the IUCN. Her research focus is on regeneration ecology, seed biophysiology and conservation and throughout her career in science she has been engaged in activities that examine the interplay of diversity, equity and inclusion in STEM disciplines.

Address: Guangxi Key Laboratory of Forest Ecology and Conservation, College of Forestry, Guangxi University, Daxuedonglu 100, Nanning 530004, Guangxi, China.

e-mail: uromi.manage.goodale@outlook.com; uromi.goodale@aya.ya le.edu

Aiwu Jiang is an Associate Professor at the College of Forestry, Guangxi University. His research focus is on breeding ecology and conservation biology, including the ecological effects of anthropogenic disturbance.

Address: Guangxi Key Laboratory of Forest Ecology and Conservation, College of Forestry, Guangxi University, Daxuedonglu 100, Nanning 530004, Guangxi, China.

e-mail: aiwuu@163.com

Jianguo Liu holds the Rachel Carson Chair in Sustainability, is University Distinguished Professor at Michigan State University and serves as director of the Center for Systems Integration and Sustainability. He is particularly interested in systems integration (e.g., integrating ecology with social sciences, policy, and advanced technologies) for addressing global sustainability challenges.

Address: Department of Fisheries and Wildlife, Center for Systems Integration and Sustainability, Michigan State University, East Lansing, MI 48823, USA.

e-mail: liuji@msu.edu

Saurav Malhotra is the Co-Founder and Designer of the Rural Futures model at the Balipara Foundation. Saurav's interests lie in maximising natural capital outcomes from land for community-led delivery of universal basic assets.
Address: Balipara Foundation, A1 Navin Enclave, Mother Teresa Road, Guwahati, Assam 781021, India.

e-mail: saurav.malhotra@baliparafoundation.com

Madhava Meegaskumbura is a Professor and a PI at Guangxi University. His research interests include life history evolution, biodiversity and evolutionary genetics.

Address: Guangxi Key Laboratory of Forest Ecology and Conservation, College of Forestry, Guangxi University, Daxuedonglu 100, Nanning 530004, Guangxi, China.

e-mail: madhava_m@mac.com

Maharaj K. Pandit is Professor of Environmental Studies at the University of Delhi, and the author of "Life in the Himalaya: An Ecosystem at Risk". A former Nee Ann Kongsi Distinguished Visiting Professor at the National University of Singapore, and a Radcliffe Fellow at the Harvard University, his work focuses on Himalayan ecology, biodiversity conservation and climate change.

Address: Department of Environmental Studies, and Delhi School of Climate Change and Sustainability, Institution of Eminence, University of Delhi, Delhi 110007, India.

e-mail: mkpandit@cismhe.org

Guangle Qiu is a Professor at the State Key Laboratory of Environmental Geochemistry, Institute of Geochemistry, Chinese Academy of Sciences. His research focus is on the biogeochemistry of mercury.

Address: Institute of Geochemistry, Chinese Academy of Sciences, Linchenxilu 99, Guiyang 550081, Guizhou, China.

e-mail: qiuguangle@vip.skleg.cn

Jianchu Xu is a Professor at the Kunming Institute of Botany, Chinese Academy of Sciences. His research focus in on land systems in coupled social-ecological systems.

Address: Kunming Institute of Biology, Chinese Academy of Sciences, \#132 Lanhei Road, Heilongtan, Kunming 650201, Yunnan, China.

e-mail: J.C.Xu@cgiar.org

Kun-Fang Cao $(\bowtie)$ is a Professor at the College of Forestry, Guangxi University, whose research focuses on plant ecophysiology, specifically, plant hydraulic structure and function, sap flow, stomatal regulation, photosynthesis, and photoprotection. Currently, he leads a long-term research plot network assessing the forest dynamics of tropical and subtropical forests in Guangxi, China.

Address: Guangxi Key Laboratory of Forest Ecology and Conservation, College of Forestry, Guangxi University, Daxuedonglu 100, Nanning 530004, Guangxi, China.

Address: State Key Laboratory for Conservation and Utilization of Subtropical Agro-Bioresources, College of Forestry, Guangxi University, Daxuedonglu 100, Nanning 530004, Guangxi, China. e-mail: kunfangcao@gxu.edu.cn

Kamaljit S. Bawa is the President of the Ashoka Trust for Research in Ecology and Evolution (ATREE), Bengaluru, India. His area of research is sustainability science.

Address: ATREE, Srirampura, Jakkur Post, Bengaluru, Karnataka 560064, India.

e-mail: Kamal.bawa@gmail.com 